Jurnal Akuntansi \& Perpajakan, Volume 1, No. 2, Januari 2020

\title{
PENGARUH TIME BUDGET PRESSURE, INDEPENDENSI DAN KOMPETENSI TERHADAP KUALITAS AUDIT
}

\author{
Malem Ukur Simangunsong \\ Sekolah Tinggi Ilmu Ekonomi Jayakarta \\ mangunsongmalem@gmail.com
}

\begin{abstract}
ABSTRAK
Penelitian ini bertujuan untuk mengetahui pengaruh time budget pressure, independensi dan kompetensi terhaddap kualitas audit. Sampel dari penelitian ini adalah 150 auditor yang bekerja pada KAP di Jakarta pusat, namun yang bisa digunakan adalah 111 kuesioner. Data yang digunakan adalah data primer yang diperoleh dengan menyebarkan kuesioner kepada responden. Penelitian ini menggunakan metode analisis regresi linear berganda. Penelitian ini menemukan hasil bahwa kompetensi dan independensi berpengaruh positif terhadap kualitas audit, hal ini berarti semakin tinggi kompetensi dan independensi yang dimiliki seorang auditor maka kualitas audit akan semakin baik. Sedangkan variabel time budget pressure berpengaruh negatif yang berarti semakin tinggi time budget pressure maka kualitas audit akan semakin menurun. Kesimpulan dari penelitian ini adalah bahwa ketiga variabel bebas dalam penelitian ini memiliki pengaruh yang signifikan terhadap kualitas audit.
\end{abstract}

Kata kunci: Time Budget Pressure,Independensi, kompetensi dan Kualitas Audit 
Jurnal Akuntansi \& Perpajakan, Volume 1, No. 2, Januari 2020

\section{PENDAHULUAN}

Dilihat dari suatu perusahaan melaporkan adanya laba bersih dengan laporan tersebut sudah diaudit oleh KAP akan tetapi, Kementerian BUMN dan Bapepam menilai bahwa laba bersih tersebut terlalu besar dan mengandung unsur rekayasa. Kesalahan itu timbul pada unit Industri Bahan Baku yaitu kesalahan berupa overstated penjualan, pada unit Logistik Sentral berupa overstated persediaan barang, pada unit pedagang besar berupa overstated persediaan dan overstated penjualan. Kesalahan penyajian yang berkaitan dengan bahwa KAP yang mengaudit laporan keuangan telah mengikuti standar audit yang berlaku, namun gagal mendeteksi kecurangan tersebut. Kasus lainnya adalah adanya KAP diindikasi melakukan kesalahan dalam mengaudit laporan keuangan suatu perusahaan. Kualitas audit merupakan fungsi jaminan dimana kualitas tersebut akan digunakan untuk membandingkan kondisi yang sebenarnya dengan yang seharusnya. Time budget pressure, Independensi dan Kompetensi apakah berpengaruh terhadap kualitas audit. Kelly dan Margheim (1990), menyebutkan salah satu penyebab penurunan kualitas audit adalah akibat dari tekanan (pressure). Dampak penurunan kualitas audit dapat menurunkan kepercayaan publik terhadap profesi akuntansi, menurunkan kredibilitas para akuntan publik atas hasil-hasil audit yang mereka lakukan. Dampak penurunan kualitas audit dapat menurunkan kepercayaan publik terhadap profesi akuntansi, menurunkan kredibilitas para akuntan publik atas hasil-hasil audit yang mereka lakukan. Kondisi ini tentu perlu mendapat perhatian oleh para praktisi maupun lembaga profesi sehingga dalam pelaksanaan penugasan audit, auditor dapat mempertahankan kualitas pekerjaannya.. Anggaran waktu audit sangat diperlukan 
Jurnal Akuntansi \& Perpajakan, Volume 1, No. 2, Januari 2020

bagi auditor dalam melaksanakan tugasnya untuk dapat memenuhi permintaan klien secara tepat waktu dan menjadi salah satu kunci keberhasilan karir auditor di masa depan. Kriteria untuk memperoleh peringkat yang baik adalah pencapaian anggaran waktu (Kelley \& Seiler, 1982). Kriteria ini memberikan tekanan bagi auditor untuk memenuhi anggaran waktu. Tekanan ini menyebabkan stres inividual yang muncul dari ketidakseimbangan antara tugas dan waktu yang tersedia serta mempengaruhi etika profesional melalui sikap, niat, perhatian, dan perilaku auditor Maka dengan itu tujuan penelitian ini adalah untuk mengetahui pengaruh time budget pressure, independensi dan kopetensi terhadap kualitas audit.

\section{LITERATUR REVIEW}

Teori kurva $\mathrm{U}$ terbalik adalah teori yang menjelaskan hubungan antara tekanan dan kinerja dan model ini yang paling banyak digunakan untuk menjelaskan hubungan antara tekanan dan kinerja. Menurut Robbins 2006 dalam Simajuntak Piter 2008 logika yang mendasari teori $\mathrm{U}$ terbalik. Teori keagenan yang dikembangkan oleh Jensen dan Meckling (1976) dan Ng (1978) dalam Mardiyah (2005) mencoba menjelaskan adanya konflik kepentingan antara manajemen selaku agen dan pemilik serta entitas lain dalam kontrak (misal kreditur) selaku prinsipal. Tekanan anggaran waktu adalah suatu kondisi dimana auditor mendapatkan tekanan dari tempatnya bekerja untuk dapat menyelesaikan tugasnya sesuai dengan waktu yang telah ditetapkan.Time budget pressure digunakan untuk menuntut auditor melakukan efisiensi waktu terhadap anggaran waktu yang telah disusun, hal ini terkait adanya pembatasan waktu yang sangat ketat. Time deadlinepressure berkaitan dengan kondisi dimana seorang auditor dituntut untuk menyelesaikan tugas audit tepat pada waktunya (Herningsih 2001 dalam Amalia Yuliana dkk, 2009). 
Jurnal Akuntansi \& Perpajakan, Volume 1, No. 2, Januari 2020

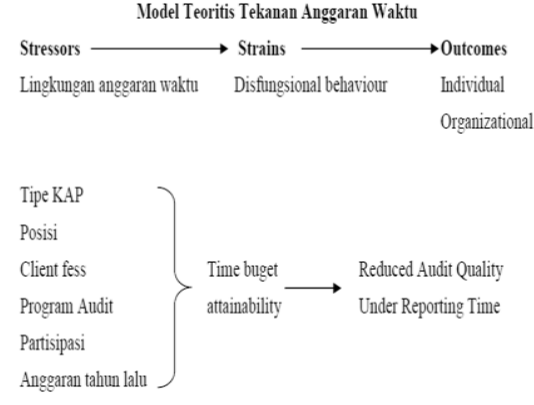

Gambar 2.2 Model Teoritis Tekanan Anggaran Waktu

Sumber : Piter (2008)

Sikap independen auditor akan didukung dengan penerapan kecermatan dan keseksamaan yang diwujudkan dengan dilakukannya review secara kritis pada setiap tingkat supervise terhadap pelaksanaan audit. Sikap independen auditor dengan didukung kecermatan dan keseksamaan yang dilakukan oleh seorang auditor diharapkan akan menghasilkan kualitas audit yang semakin baik, setiap pendapat yang diberikan oleh auditor dan penyajiannya yang telah mengikuti pedoman yang tercantum dalam standar auditing (Hardiningsih, 2012). Independensi menurut Arens dkk (2012 :111) diartikan sebagai mengambil sudut pandang yang tidak bias. Seorang auditor tidak hanya independen dalam fakta saja, namun juga harus independen dalam penampilan. Independen dalam fakta (independenden in fact) akan ada jika auditor mempertahankan sikap yang tidak bias sepanjang proses audit berlangsung, sementara independen dalam penampilan (independent in appearrance) adalah hasil dari interpretasi lain atas independensi ini. Dalam melaksanakan tugasnya sebagai seorang auditor dibutuhkan mutu personal yang baik, pengetahuan yang memadai, serta keahlian khusus dibidangnya. Standar umum pertama (SA seksi 210 dalam SPAP 2001) menyebutkan bahwa audit harus dilaksanakan oleh seorang atau lebih yang memiliki keahlian dan pelatihan teknis yang memadai sebagai auditor kompetensi berkaitan dengan keahlian profesional yang dimiliki oleh auditor sebagai hasil dari pendidikan formal, ujian profesional, maupun keikutsertaan dalam pelatihan, seminar (Elyzabet I. Marpaung, 2012. Memahami kriteria yang digunakan dan harus kompoten untuk mengetahui jenis 
Jurnal Akuntansi \& Perpajakan, Volume 1, No. 2, Januari 2020

serta jumlah bukti yang akan dikumpulkan guna mencapai kesimpulan yang tepat setelah memeriksa bukti itu ( Arens dkk 2012 : 5). Januar Dwi Widya Rahmawati (2013) melakukan penelitian pengaruh Kompetensi dan Independensi terhadap kualitas audit dengan hasil bahwa secara parsialvariabel-variabel independen yaitu kompetensi (terdiri dari pengetahuan danpengalaman) dan independensi (terdiri dari lama hubungan dengan klien dan tekanandari klien) berpengaruh signifikan secara parsial terhadap kualitas audit dengan arahpengaruh positif untuk variabel pengetahuan, pengalaman, dan lama hubungandengan klien. Artinya semakin meningkat pengetahuan, pengalaman dan lamahubungan auditor dengan klien maka akan meningkatkan kualitas audit yangdiberikan. Namun untuk variabel tekanan dari klien diperoleh hasil negatif, artinyasemakin tinggi tekanan dari klien maka akan menurunkan kualitas audit yangdiberikan.Secara simultan diperoleh hasil bahwa variabel pengalaman, pengetahuan, lamahubungan dengan klien, dan tekanan dari klien secara bersama-sama berpengaruhsecara signifikan terhadap kualitas audit.

Reni Febriyanti (2014) Pengaruh Independensi, Due Professional Care dan Akuntabilitas Terhadap Kualitas Audit (Studi Empiris Pada Kantor Akuntan Publik di Kota Padang dan Pekanbaru) dengan hasil Independensi tidak berpengaruh signifikan positif terhadap kualitas audit pada Kantor Akuntan Publik (KAP) di Provinsi Sumatera Barat dan Riau Due profesional Care berpengaruh signifikan positif terhadap kualitas audit pada Kantor Akuntan Publik (KAP) di Provinsi Sumatera Barat dan Riau Akuntabilitas tidak berpengaruh signifikan terhadap kualitas Audit pada Kantor Akuntan Publik (KAP) di Provinsi Sumatera Barat dan Riau Beberapa penelitian sebelumnya membahas tentang pengaruh akuntabilitas dan kompetensi auditor terhadap kulitas 
Jurnal Akuntansi \& Perpajakan, Volume 1, No. 2, Januari 2020

audit (Fenny Suharjo, 2012) yang

menyimpulkan bahwa akuntabilitas dan kompetensi auditor berpengaruh positif tehadap kualitas audit. Sehingga motivasi dan implementasi pertanggungjawaban sosial dalam diri auditor yang lebih besar serta kompetensi yang baik dari akuntan makan akan membuat semakin baik kualitas audit yang dihasilkan. Sementara itu pada tahun 2013A Basit Fauzi Nugraha melakukan penelitian terhadap auditor Inspektorat dan BPK RI Perwakilan Provinsi Jawa Barat) dengan hasil Secara parsial, Pengalaman, Due Professional Care dan Independensi auditor berpengaruh signifikan terhadap kualitas audit. Pengalaman, Due Professional Care dan Independensi auditor juga secara simultan memberikan kontribusi atau pengaruh terhadap kualitas audit pada Inspektorat dan BPK RI Perwakilan Provinsi Jawa Barat. Diantara variabel independen, pengalaman auditor memberikan pengaruh yang lebih besar terhadap kualitas audit pada Inspektorat dan BPK RI Perwakilan Provinsi Jawa Barat dibanding Due Professional Care dan Independensi. Arah hubungan positif menunjukkan bahwa semakin berpengalaman serta memiliki sikap due Professional Care dan independen pada diri auditor diduga akan meningkatkan kualitas audit pada Inspektorat dan BPK RI Perwakilan Provinsi Jawa Barat.

Kemudian penelitian yang dilakukan oleh Muhammad Kadhafi1Nadirsyah2, Syukriy Abdullah2 ,2014, responden penelitian ini sebanyak 32 orang yang terdiri dari: Auditor Inspektorat Aceh.

Metode yang digunakan adalah sensus, yaitu seluruh elemen populasi diselidiki satu persatu dalam pengumpulan data. Metode analisis yang digunakan adalah regresi linier berganda.Hasil penelitian menunjukkan bahwa: independensi, etika dan standar audit secara bersama-sama berpengaruh terhadap 
Jurnal Akuntansi \& Perpajakan, Volume 1, No. 2, Januari 2020

kualitas audit (2) independensi, berpengaruh terhadap kualitas audit (3) etika berpengaruh terhadap kualitas audit (4) standar audit berpengaruh terhadap kualitas audit. Untuk Tekanan anggaran waktu sudah pernah dilakukan penelitian oleh peneliti-peneliti sebelumnya antara lain penelitian yang dilakukan oleh Rizki Amelia 2013 yang menyimpulkan bahwa Hasil penelitian menunjukkan bahwa time budget pressure memiliki pengaruh negatif yang signifikan terhadap kualitas audit yang artinya bahwa semakin tinggi time budget pressure maka semakin rendah kualitas auditnya. Time budget pressure memiliki pengaruh sebesar $47,06 \%$ terhadap kualitas audit dan sisanya sebesar $52,94 \%$ dipengaruhi oleh faktor lain seperti independensi, kompetensi, akuntabilitas dan hal lainnya yang tidak diteliti. Berdasarkan penelitian terdahulu yang membuktikan keterkaitan time budget pressure Soobaroyen dan Chengabroyan (2005) menemukan bahwa time budget yang ketat sering menyebabkan auditor meninggalkan bagian program audit penting dan akibatnya menyebabkan penurunan kualitas audit. Kelley (2005) mendukung pendapat tersebut dengan menyatakan bahwa penurunan kualitas audit telah ditemukan akibat ketatnya time budget. Tampak bahwa tekanan anggaran waktu akan menghasilkan kinerja buruk auditor. Kualitas audit bisa menjadi semakin buruk, bila alokasi waktu yang dianggarkan tidak realistis dengan kompleksitas audit yang diembannya. Piter Simanjuntak (2008) menghasilkan temuan terkait yang menunjukkan semakin menurunnya kualitas audit dikarenakan anggaran waktu yang sangat ketat.

\section{METODE}

Rancangan penelitian yang akan digunakan untuk menganalisis penelitian mengenai "pengaruh time budget pressure, independensi dan kompetensi terhadap kualitas audit “, dengan menggunakan metode survei (survey methods) melalui 
Jurnal Akuntansi \& Perpajakan, Volume 1, No. 2, Januari 2020

teknik pengumpulan data dengan

kuesioner. Data yang digunakan dalam penelitian ini adalah data primer. Data primer diperoleh dengan menggunakan daftar pertanyaan (kuesioner) yang telah terstruktur dengan tujuan untuk mengumpulkan informasi dari auditor pada KAP di DKI Jakarta. Kuesioner yang dikirimkan disertai dengan surat permohonan serta penjelasan tentang tujuan penelitian yang dilakukan. Petunjuk pengisian kuisioner dibuat sederhana dan sejelas mungkin untuk memudahkan pengisian jawaban sesungguhnya dengan lengkap. Untuk menentukan data apa yang diperlukan dalam penelitian, maka terlebih dahulu perlu pengukuran variabel-variabel seperti telah diinventarisasikan dalam kerangka pikiran dengan maksud untuk menentukan indikator-indikator variabel yang bersangkutan. Pengujian hipotesis dilakukan untuk mengetahui apakah hipotesis dalam penelitian diterima atau ditolak. Pengujian hipotesis pada penelitian ini dilakukan dengan menggunakan analisis regresi berganda untuk mengetahui adanya pengaruh variabel bebas terhadap variabel terikat secara parsial dan simultan.Alat uji hipotesis dalam penelitian ini adalah regresi berganda. Regresi berganda adalah regresi yang memiliki satu variabel dependen dan lebih dari satu variabel independen .Model persamaan regresi berganda adalah sebagai berikut:

$\mathrm{Y}=\mathrm{b} 1 \mathrm{X} 1+\mathrm{b} 2 \mathrm{X} 2+\mathrm{b} 3 \mathrm{X} 3+\ldots . . \mathrm{e}$

$\mathrm{Y}=$ Variabel Kualitas Audit

$\mathrm{X} 1$ = Variabel tekanan anggaran waktu Audit

$\mathrm{X} 2$ = Independensi

X3 = Kompetensi

Adapun hipotesis yang akan diuji dalam penelitian ini adalah sebagai berikut :

H1 : Semakin tinggi tingkat tekanan anggaran waktu akan berhubungan dengan semakin tingginya tingkat penurunan kualitas audit.

H3 : Kompetensi berpengaruh terhadap kualitas audit. 
Jurnal Akuntansi \& Perpajakan, Volume 1, No. 2, Januari 2020

$\mathrm{H} 2$ : Independensi berpengaruh terhadap kualitas audit.

Hasil penelitian menggambarkan temuan utama dari penelitian. Sajian dalam hasil dan pembahasan ditulis secara bersistem, hanya hasil.

\section{HASIL DAN PEMBAHASAN}

Penelitian menggunakan variable bebas Independensi, Kompetensi dan time budget pressuredan variabel terikat, yaitu kualitas audit. Statistik deskriptif dari masing-masing variabel adalah sebagai berikut :

Hasil tampilan Output SPSS menunjukkan jumlah responden $(\mathrm{N})$ ada 111. Terlihat nilai skewnes dan kurtosis mendekati nilai nol yang berarti bahwa data berdistribusi normal (Imam Ghozali : 21). Skweness dan kurtosis merupakan ukuran untuk melihat apakah data terdistribusi secara normal atau tidak. Skewness mengukur kemencengan dari data dan kurtosis mengukur puncak dari distribusi data. Data yang berdistribusi secara normal mempunyai nilai skewnss dan kurtosis mendekati nol.

\section{Uji Validitas}

Uji validitas dilakukan untuk mengukur sah atau valid tidaknya suatu kuesioner. Suatu kuesioner dikatakan valid jika pertanyaan pada kuesioner mampu mengungkapkan sesuatu yang akan diukur oleh kuesioner tersebut (Ghozali, 2013). Dasar pengambilan keputusan dalam uji validitas adalah:

1. Jika nilai $r_{\text {hitung }}>$ nilai $r_{\text {tabel }}$ pada nilai signifikasi 5\%, maka item angket dinyatakan valid.

2. Jika nilai $r_{\text {hitung }}<$ nilai $r_{\text {tabel }}$ pada nilai signifikasi 5\%, maka item angket dinyatakan tidak valid.

Uji validitas dilaksanakan dengan rumus korelasi bivariate person. Uji validitas dalam penelitian ini dilakukan dengan alat bantu program SPSS versi 21. Adapun ringkasan hasil uji validitas sebagaimana data dalam tabel berikut ini. 
Jurnal Akuntansi \& Perpajakan, Volume 1, No. 2, Januari 2020

Uji Validitas Variabel Time Budget

Pressure

Berdasarkan hasil pengujian validitas diatas, diketahui bahwa empat butir pernyataan yang digunakan dalam instrumen penelitian memiliki $\mathrm{r}$ hitung lebih besar dari $r$ table dengan signifikansi $5 \%$. Jika $r$ hitung lebih besar dari $r$ table dan nilai positif maka butir atau pernyataan atau indicator tersebut dinyatakan valid Ghozali 2013: 53) Dengan kata lain butir butir pernyataan tersebut dapat mewakili atau membentuk konstruk dari variabel time budget pressure.

\section{Uji Validitas Variabel Independensi}

Enam pernyataan yang diajukan memiliki nilai $\mathrm{r}$ hitung lebih besar dari $\mathrm{r}$ tabel pada nilai signifikansi $5 \%$.Hal ini dapat diartikan bahwa masing-masing butir pernyataan tersebut adalah valid. Dengan kata lain butir - butir pernyataan tersebut dapat mewakili atau membentuk konstruk dari variabel Independensi.

\section{Uji Validitas Variabel Kompetensi}

Enam pernyataan yang diajukan memiliki nilai $r$ hitung lebih besar dari $r$ tabel pada nilai signifikansi $5 \%$.Hal ini dapat diartikan bahwa masing-masing butir pernyataan tersebut adalah valid. Dengan kata lain butir - butir pernyataan tersebut dapat mewakili atau membentuk konstruk dari variabel Kompetensi.

\section{Uji Validitas Variabel Kualitas Audit}

Enam pernyataan yang diajukan memiliki nilai $\mathrm{r}$ hitung lebih besar dari $\mathrm{r}$ tabel pada nilai signifikansi $5 \%$.Hal ini dapat diartikan bahwa masing-masing butir pernyataan tersebut adalah valid. Dengan kata lain butir - butir pernyataan tersebut dapat mewakili atau membentuk konstruk dari variabel Kualitas Audit.

\section{Uji Reliabilitas Data}

Uji konsistensi internal (uji reliabilitas) dilakukan dengan menghitung koefisien (cronbach) alpha dari masingmasing instrumen dalam suatu variabel.

Uji reliabilitas adalah istilah yang digunakan untuk menunjukkan sejauh 
Jurnal Akuntansi \& Perpajakan, Volume 1, No. 2, Januari 2020

mana hasil pengukuran relatif konsisten apabila pengukuran diulang dua kali atau lebih. Reliabilitas data pada penelitian ini diuji dengan menggunakan Inter-item Consistency. Reliability yang melihat Cronbach's coefficient alpha sebagai koefisien dari reliabilitas. Cronbach's alpha adalah koefisien reliabilitas yang menunjukkan bagaimana bagian-bagian dari suatu set berkorelasi secara positif satu sama lainnya (Sekaran, 2003: 307). Hasil uji reliabilitas diperoleh nilai alpha semua variabel lebih besar dari nilai 0,60 . Oleh karena itu, dapat disimpulkan bahwa semua item dalam penelitian ini reliabel atau konsisten, sehingga dapat digunakan sebagai instrumen penelitian.

\section{Pengujian Asumsi Klasik}

\section{Uji Normalitas}

$$
\text { Berdasarkan hasil pengujian }
$$
normalitas residual, diketahui bahwa residual model persamaan regresi memiliki nilai asymp.sig. 0,698 >alpha 0,05. Maka $\mathrm{H}_{0}$ gagal ditolak, artinya sebaran nilai residual pada model persamaan regresi dinyatakan berdistribusi normal.

\section{Uji Multikolinearitas}

Berdasarkan tabel di atas, diperoleh nilai tolerance lebih besar 0,10 dan nilai VIF lebih kecil 10,00 sehingga dapat disimpulkan data tidak terjadi masalah multikolinearitas

\section{Uji Heteroskedastisitas}

Berdasarkan uji heteroskedastisitas dengan metode glesjer diperoleh nilai signifikansi lebih besar 0,05 , sehingga dapat disimpulkan data tidak terjadi masalah heteroskedastisitas.

\section{Autokorelasi}

Berasarkan tabel di atas diketahui bahwa nilai d 1,779 terletak di antara nilai du 1,736 dan 4-du 2,264, maka dapat dikatakan tidak ada autokorelasi.

\section{Pengaruh Time Budget Pressure terhadap kualitas audit}


Jurnal Akuntansi \& Perpajakan, Volume 1, No. 2, Januari 2020

Hasil ini

konsisten

penurunan kualitas audit telah ditemukan denganpenelitian yang dilakukan oleh Kelley dan Margeheim (1990), Otley dan Pierce(1996), yang menyebutkan bahwa hubungan antara tekanan anggaran waktu danperilaku penurunan kualitas audit adalah linier walaupun literatur psikologimendugateori $\quad U$ terbalik berhubungan dengan efek tekanan. Hasil yang sama juga diperoleholeh Conram et al (2003) dimana auditor cenderung untuk lebih memilih informasiyang dianggap paling penting dibawah tekanan anggaran waktu, hal ini akanmenyebabkan pengujian yang telah direncanakan tidak sepenuhnya dilaksanakan.Soobaroyen

Chengabroyan (2005) juga menemukan bahwa time budget yang ketat sering menyebabkan auditor meninggalkan bagian program audit penting dan akibatnya menyebabkan penurunan kualitas audit. Kelley (2005) mendukung pendapat tersebut dengan menyatakan bahwa akibat ketatnya time budget.

\section{Pengaruh Independensi terhadap}

\section{kualitas audit}

Dalam penelitian ini teori agency mendukung penuh independensi karena dalam teori agency diharapan ada penyampaian informasi yang benar antara pengelola dan pemilik saham yang mana informasi ini tersajikan dalam sebuah laporan keuangan yang kualitas nya hanya mampu ditentukan oleh auditor yang memiliki indepedensi serta mampu mengatasi tekanan-tekanan baik dari pihak manajemen ataupun pihak lain yang berkepentingan atas hasil audit laporan keuangan(Hidayat : 2011).Hasil pengujian ini sejalan dengan penelitian yang dilakukan oleh A Basit Fauzi Nugraha melakukan penelitian terhadap auditor Inspektorat dan BPK RI Perwakilan Provinsi Jawa Barat) dengan hasil Secara parsial, Pengalaman, Due Professional Care dan Independensi auditor 
Jurnal Akuntansi \& Perpajakan, Volume 1, No. 2, Januari 2020

berpengaruh signifikan terhadap kualitas audit. Pengalaman, Due Professional Care dan Independensi auditor juga secara simultan memberikan kontribusi atau pengaruh terhadap kualitas audit pada Inspektorat dan BPK RI Perwakilan Provinsi Jawa Barat.

Pengaruh Kompetensi terhadap kualitas audit

Kesimpulan kompetensi berpengaruh signifikan terhadap Kualitas AuditKonstribusi Kompetensi mempengaruhi Kualitas audit dalah sebesar $0,471^{2}=0,221$ atau $22,1 \%$. Hasil pengujian ini sejalan dengan Januar Dwi Widya Rahmawati (2013) melakukan penelitian pengaruh Kompetensi dan Independensi terhadap kualitas audit dengan hasil bahwa secara parsialvariabel-variabel independen yaitu kompetensi dan independensi berpengaruh signifikan secara parsial terhadap kualitas audit dengan arahpengaruh positif untuk variabel pengetahuan, pengalaman, dan lama hubungandengan klien.

\section{Uji Koefisien Determinasi (Adj. $\left.R^{2}\right)$}

Uji koefisien determinasi diamati melalui nilai adjusted $R^{2}$. Berdasarkan analisis data menggunakan alat bantu program SPSS versi 21 diperoleh nilai koefisien determinasi $\left(\mathrm{R}^{2}\right)$ sebesar 0,608 . Arti dari koefisien ini adalah bahwa sumbangan relatif yang diberikan oleh kombinasi variabel time budget pressurre, Independensi dan kompetensi terhadap kualitas audit adalah sebesar $60,8 \%$ sedangkan sisanya dipengaruhi oleh variabel lain yang tidak diteliti dalam penelitian ini.

\section{KESIMPULAN}

Hasil uji koefisien regresi (uji t) atas variabel time budget pressure memiliki pengaruh signifikan dengan hasil negatif yang artinya semakin tinggi time budget pressure maka akan berpengaruh negatif terhadap kualitas audit. Hasil penelitian ini 
Jurnal Akuntansi \& Perpajakan, Volume 1, No. 2, Januari 2020

sejalan dengan penelitian yang dilakukan

oleh Piter simajuntak yang menyatakan

bahwa terdapat pengaruh negatif yang signifikan antara time budget pressure dengan kualitas audit.

Hasil uji koefisien regresi (uji t) atas variabel Kompetensi auditor secara individu berpengaruh signifikan terhadap variabel kualitas audit. Pengaruh kompetensi terhadap kualitas audit adalah posistif yang berarti semakin tinggi kompetensi auditor maka kualitas audit menjadi semakin tinggi.

Hasil uji koefisien regresi (uji t) atas variabel independensiberpengaruh signifikan terhadap variabel kualitas audit. Pengaruh independensi terhadap kualitas audit adalah posistif yang berarti semakin tinggiindependensi maka kualitas audit menjadi semakin tinggi.

Hasil uji koefisien regresi secara serentak/ simultan ( uji F) seluruh variabel time budget pressure, independensi dan kompetensi secara bersama - sama/ secara simultan berpengaruh terhadap kualitas audit. Hal ini berarti hipotesis Ha dalam penelitian ini diterima.

Sumbangan relatif yang diberikan oleh kombinasi variabel time budget pressurre, Independensi dan kompetensi terhadap kualitas audit adalah sebesar $60,8 \%$ sedangkan sisanya dipengaruhi oleh variabel lain yang tidak diteliti dalam penelitian ini. Makna hasil penelitian mengenai pengaruh variabel time budget pressure, independensi dan kompetensi terhadap variabel kualitas audit ini dapat memberi wawasan dan pemahaman baru bagi para praktisi auditing yaitu para auditor agar dapat meningkatkan kualitas dari pekerjaan auditnya. Bagi pembuat standar, hasil penelitian ini dapat dijadikan pertimbangandalam setiap penyusunan standar auditing.Serta bagi klien dan stakeholder, hasil penelitian ini dapat menambah pengetahuan mereka mengenai pengaruh variabletime budget pressure, independensi dan kompetensi terhadap 
Jurnal Akuntansi \& Perpajakan, Volume 1, No. 2, Januari 2020

variabel kualitas audit dalam melaksanakan

pekerjaan auditnya secara berkualitas.

Mengoptimalkan peneliti menggunakan

network atau koneksi yang dikenal di

Kantor Akutan Publik pada saat penyebaran

kuesioner agar lebih pasti tingkat pengembaliannya.

Melakukan ekstensi atas penelitian ini dengan menambah variabel yang mungkin dapat mempengaruhi Kualitas Audit, misalnya individual motivation dan workgroup effectiveness.

Untuk penelitian selanjutnya diharapkan untuk memperbanyak jumlah sampel Kantor Akuntan Publik yang diteliti.

\section{REFERENSI}

Amalia Yuliana, dkk. (2009). Pengaruh Time Pressure dan Resiko Audit Terhadap Ekonomi. Universitas Jambi.

Aprianti, Deva. Pengaruh kompetensi, independensi, dan keahlian profesional terhadap kualitas audit dengan etika auditor sebagai variabel moderasi (studi kasus pada kantor akuntan publik di wilayah Jakarta Selatan). UIN Syarif Hidayatullah Jakarta.

Arens a. Alvin, Elder j. Randal, Beasley S. Mark. 2012. Auditing dan Pelayanan Verifikasi. Edisi Kesembilan. Edisi Bahasa Indonesia. Jakarta: Indeks

Basit Fauzi NugSraha Fauzi Basit. 2013. "Pengaruh Pengalaman, Due Professional Care, dan Independensi Auditor terhadap Kualitas Audit “ DeAngelo, L.E., 1981. "Auditor Size and Auditor Quality”, Journal of AccountingandEconomics

Eunike Christina Elfarini.2007 .Pengaruh Independensi dan Kompetensi Auditor Terhadap Kualitas Audit .FEUN Semarang.

Febriyanti Reni . 2014 "Pengaruh Independensi, Due Profesional Care dan Akuntabilitas Terhadap Kualitas Audit “ 
Jurnal Akuntansi \& Perpajakan, Volume 1, No. 2, Januari 2020

Kane, G., \& U. Velury. 2005. The Impact Of

Managerial Ownership On The

Likelihood OfProvision Of High

Quality Auditing Services, Review Of

Accounting \& Finance.

Kelley, T. and Seiler, R.E. 1982. "Auditor

Stress and Time Budget". The CPA

Journal, December. pp. 24-34.

Hardiningsih dan Oktaviani. 2012.

Pengaruh Due Professional Care,

Etika dan Tenur terhadap Kualitas

Audit. (Perspektif Expectation

Theory). Unisbank Semarang

Hutabarat Goodman. 2012. "Pengaruh

Pengalaman Time Budget Pressure

dan Etika Auditor terhadap Kualitas

Audit”

McNamara, M. S. and Liyanarachchi. 2004. Time Budget Pressure And Auditor Dysfuntional Behaviour Within An Occupation Stress Model. Department of Accountancy and Business Law. University Of Otago. New Zealand
Meutia, Inten. 2004. Pengaruh Independensi Auditor Trhadap manajemen Labauntuk KAP Big Five dan Non Big Five. Jurnal Riset Akuntansi September Volume 3 Nomor 7

Muhammad Kadhafi, Nadirsyah dan Syukriy Abdullah. 2014. Pengaruh Independensi, Etika Dan Standar Audit Terhadap Kualitas Audit Inspektorat Aceh. Jurnal Akuntansi. ISSN: 23020164.

Nafi Yuliantoro. 2012. Pengaruh Time Budget Pressure dan Independensi Auditor terhadap Kualitas Audit (Studi Empiris pada KAP di Daerah Istimewa Yogyakarta). Kajian Pendidikan dan Akuntansi Indonesia, Edisi III Volume I.

PiterSimanjuntak, "Pengaruh Time Budget Presure dan Resiko KesalahanTerhad ap Penurunan Kualitas Audit (Reduced Audit Quality)"Universitas Diponegoro, Semarang, 2008 
Jurnal Akuntansi \& Perpajakan, Volume 1, No. 2, Januari 2020

Rahmawati, Januar Dwi Widya. 2013.

"Pengaruh Kompetensi dan

Independensi Terhadap Kualitas

Audit" Jurnal Ilmiah Mahasiswa

FEB Vol 1 No 1 Universitas

Brawijaya Semester ganjil 2012/2013.

Sukriah, Ika. Akram dan Biana Adha Inapty. (2009). Pengaruh Pengalaman Kerja, Independensi, Obyektifitas,
Integritas, dan Kompetensi Terhadap

Kualitas Hasil Pemeriksaan.

Palembang: SNA XII.

Yenny. 2009. Pengaruh Pengalaman Kerja,

Independensi,

Objektivitas,

Integritas, dan Kompetensi Auditor

terhadap Kualitas Audit yang

dihasilkan Auditor Kantor Akuntan

Publik (KAP) 